\title{
Human medical view on zoonotic parasites
}

\author{
Antti Lavikainen \\ From Parasite infections of domestic animals in the Nordic countries - emerging threats and challenges. \\ The 22nd Symposium of the Nordic Committee for Veterinary Scientific Cooperation (NKVet) \\ Helsinki, Finland. 7-9 September 2008
}

\section{Summary}

From medical point of view, a zoonosis is any infectious disease that is naturally transmissible from vertebrate animals to humans [1]. A stricter definition is a disease that normally exists in other vertebrate animals, but can be accidentally transmitted to humans [2]. In Nordic countries, parasites are rare (and zoonotic parasites even more unusual) causative agents of human infections probably due to good hygiene and climatic conditions. In most cases, parasitic infections are of foreign origin, except for some relatively common indigenous infestations such as enterobiasis (caused by the human pinworm, Enterobius vermicularis) and pediculosis (caused by the human head louse, Pediculus humanus).

Worldwide, the most significant genus of human parasites is Plasmodium. It is the causative agent of malaria, a severe tropical protozoan disease, which kills globally more than one million people every year [3]. In Finland, about twenty cases of malaria are diagnosed annually [4]. In 2007, P. knowlesii infection was diagnosed in Finland in a tourist who had traveled in Malay Peninsula [4]. P. knowlesii is a Plasmodium of monkeys. This was second reported case of $P$. knowlesii malaria in a tourist. During the $19^{\text {th }}$ century, malaria was an indoors transmitted disease in Finland, as Anopheles mosquitoes hibernated in peoples' households [5].

Intestinal parasitoses are the most common parasitic infections. Among Finnish asymptomatic population, pathogenic intestinal parasites (mostly Giardia lamblia) can be found from $1.5 \%$ of people [6]. However, only 300 cases of clinical giardiasis are diagnosed in Finland annually [7], and reported numbers of diagnosed amebiasis cases (caused by Entamoeba histolytica) range from 30 to more than $100[7,8]$. These protozoans are human parasites, and infections caused by them can occur through

Department of Bacteriology and Immunology, Haartman Institute, University of Helsinki, Finland contaminated food, water or by faecal-oral route. According to the statistics of the Parasitological unit of HUSLAB (Laboratory of Hospital District of Helsinki and Uusimaa county, Finland) from 2005 to 2007, the most important intestinal helminthes were pinworms, the human whipworm (Trichuris trichiura) and intestinal roundworms (Ascaris spp.). The swine roundworm (Ascaris suum), is a zoonotic parasite, but it was not routinely differentiated from human roundworm (A. lumbricoides). Formerly, the broad fish tapeworm (Diphyllobothrium latum) was a major health problem in Finland, and it has been called "the national parasite of Finland" [9,10]. Although it has been diminished drastically, it has not been totally eradicated. Around twenty human cases are still diagnosed annually in Finland, and the situation is similar in Sweden [11]. In contrast to diphyllobothriasis, which is mostly an indigenous disease, human intestinal taeniases are imported cases. About a handful of taeniasis cases are diagnosted in HUSLAB yearly, and the beef tapeworm (Taenia saginata) is more common finding than the pork tapeworm ( $T$. solium). In the strict sense (see the definition above), diphyllobothriasis and taeniases should not be called zoonoses, since humans are important definitive hosts of D. latum and essential for T. saginata and T. solium, although vertebrate animals (fishes, cattle and swine, respectively) act as sources of human infections.

Echinococcus spp. are the most important zoonotic cestodes worldwide. Their larvae are causative agents of serious diseases called echinococcoses. Until 1960's, human cystic echinococcosis was a significant public health problem among reindeer herding Sámi population in Swedish and Norwegian Lapland [12]. Human cases were found also in Finnish Lapland, but only few reports have been published. Later, the parasite was eradicated from the reindeer-dog cycle, and endemic human cases have not been diagnosed for several decades. In the Parasitological unit of HUSLAB, eight echinococcosis cases were diagnosed between 2002 and 
2008. These cases cover most of the diagnoses in Finland during that time period. All of them were caused by so-called sheep strain of E. granulosus. One of the patients was a Finn, but an endemic infection was excluded by the strain determination.

Another endemic zoonotic parasitosis, which seems to be disappeared from Nordic countries as a human infection, is trichinellosis. This disease caused by larvae of nematodes of the genus Trichinella has not been diagnosed for a long time. This contrasts the fact that Trichinella spp. are common in wild and domestic animals [13].

Several exotic parasites, which occur as sporadic companions of travelers, can cause tissue lesions and even systemic disease. For example, leishmaniasis is the term given to diseases caused by protozoans of the genus Leishmania[14]. These parasites are transmitted by sand flies, and small rodents and dogs are the reservoir of infection. There are two main types of clinical disease, cutaneous and systemic leishmaniases.

Larvae of gastrointestinal nematodes of dogs and cats (Toxocara canis and T. cati, respectively), can cause disease called visceral larva migrans in humans, chiefly in children $[15,16]$. Larvae migrate through inner organs and cause mechanical damage and eosinophilic lesions. Toxocara spp. are geographically widely distributed. Larva migrans is obviously a underdiagnosed zoonosis, and its prevalence in Nordic countries has not been studied recently. In HUSLAB material in 2007, seven patients had positive toxocariasis serology. One of these was most probably an unspecific seroreactivity because the same sample responded also against several other helminth antigens. Six patients were children (age of 216 years) and one was an elder person (75 years).

Toxoplasmosis is a disease caused by the protozoan parasite, Toxoplasma gondii which infects up to onethird of the world human population [17]. The definitive host of T. gondii is the cat; humans become infected by ingesting oocysts (e.g., by eating vegetables contaminated with cat faeces or soil) or tissue cysts in meat. Toxoplasmosis in neonates and immunocompromised patients can lead to severe disease and death. It has been estimated that 50-60 infants suffer from congenital toxoplasmosis annually (prevalence 1/1000) in Finland [18]. However, reported prevalences in Sweden, Norway and Denmark are much lower $(0.73-3.1 / 10,000)$ [19-21]. Anyway, due to the relatively high prevalence, indigenous occurrence and severe clinical manifestations toxoplasmosis can be considered to be one of the most important true zoonotic parasitoses in the Nordic countries.

In order to understand the transmission dynamics of zoonotic parasitic infections to humans, it is essential to have knowledge on the life cycle and prevalence of infection in other animals, both domestic and wild.
Published: 13 October 2010

\section{References}

1. World Health Organization: Zoonoses. [http://www.who.int/topics/ zoonoses/en/]

2. Bannister BA, Begg NT, Gillespie SH: Infectious Disease. Oxford: Blackwell Science 1996, 392.

3. World Health Organization: Malaria. [http://www.who.int/mediacentre/ factsheets/fs094/en/index.html]

4. Siikamäki H: Malariatapausten määrä pysyi ennallaan. Suomen Lääkärilehti 2008, 63:1847.

5. Huldén L, Huldén L, Heliövaara K: Endemic malaria: an 'indoor' disease in northern Europe. Historical data analysed. Malaria Journal 2005, 4:19.

6. Siikamäki H, Kyrönseppä H, Jokiranta S: Suoliston parasiitti-infektiot. Duodecim 2002, 118:1235-1247.

7. National Public Health Institute: the Statistical Database of the Infectious Diseases Register. [http://www3.ktl.fi/].

8. Nohynek H, Siikamäki H, Peltonen R: Matkailijoiden infektiot. Mikrobiologia ja infektiosairaudet // Helsinki: Kustannus Oy DuodecimP Huovinen, S Meri, H Peltola, M Vaara, A Vaheri, V Valtonen , 1 2003, 653-668.

9. B von Bonsdorff: The fish tapeworm, Diphyllobothrium latum; a major health problem in Finland. World Med J 1964, 11:170-172.

10. Konttinen $Y$, Hasenson S, Valovirta I, Malmström M, Ikonen E, Virtanen jal: Unohdettu kansallisloinen-tapausselostus ja lyhyt kirjallisuuskatsaus. Duodecim 1997, 113:1549.

11. Dupouy-Camet J, Peduzzi R: Current situation of human diphyllobothriasis in Europe. Eurosurveill 2004, 9:31-35.

12. Lavikainen A: Ihmisen ekinokokkitauti Suomen, Ruotsin ja Norjan Lapissa. Suomen Eläinlääkärilehti 2005, 110:7-13.

13. L Oivanen L, Kapel CM, Pozio E, La Rosa G, Mikkonen T, Sukura A: Associations between Trichinella species and host species in Finland. J Parasitol. 2002, 88:84-8.

14. Király C: Kasvojen iholeishmanioosi etelänmatkan tuliaisena. Duodecim 1995, 111:1104.

15. Raether W: Gastrointestinal nematodes in dogs and cats. Parasitology in focus Berlin: Springer-VerlagH Mehlhorn 1988, 841.

16. Vuento Risto: Koti- ja lemmikkieläimet tartuntatautien lähteenä. Duodecim 1994, 110:555

17. Birgisdóttir A, Asbjörnsdottir H, Cook E, Gislason D, Jansson C, Olafsson I, Gislason T, Jogi R, Thjodleifsson B: Seroprevalence of Toxoplasma gondii in Sweden, Estonia and Iceland. Scand J Infect Dis 2006, 38:625-631.

18. Lappalainen M: Raskaudenaikaista toksoplasmainfektiota kannattaa seuloa? Suomen Lääkärilehti 1996, 51:1316.

19. Evengård B, Petersson K, Engman ML, Wiklund S, Ivarsson SA, TeärFahnehjelm K, Forsgren M, Gilbert R, Malm G: Low incidence of toxoplasma infection during pregnancy and in newborns in Sweden. Epidemiol Infect 2001, 127:121-127.

20. Schmidt DR, Hogh B, Andersen O, Fuchs J, Fledelius H, Petersen E: The national neonatal screening programme for congenital toxoplasmosis in Denmark: results from the initial four years, 1999-2002. Arch Dis Child 2006, 91:661-665.

21. Jenum PA, Stray-Pedersen B, Melby KK, Kapperud G, Whitelaw A, Eskild A, Eng J: Incidence of Toxoplasma gondii infection in 35,940 pregnant women in Norway and pregnancy outcome for infected women. J Clin Microbiol 1998, 36:2900-2906.

doi:10.1186/1751-0147-52-S1-S4

Cite this article as: Lavikainen: Human medical view on zoonotic parasites. Acta Veterinaria Scandinavica 2010 52(Suppl 1):S4. 